IНТЕРМАРУМ: історія, політика, культура. - Вип. 7.

UDC 94(477) «1932/1933»

DOI $10.33287 / 112005$

Podobied Olena,

Doctor of Historical Sciences, Associate Professor, Professor at the Department of Source Studies and Special Historical Sciences, National Pedagogical Dragomanov University o.a.podobyed@npu.edu.ua ORCID: https://orcid.org/0000-0002-7819-1439

\title{
«THE BLACK DEEDS OF THE KREMLIN: A WHITE BOOK». UKRAINIAN EMIGRANTS TESTIFY ABOUT HOLODOMOR 1932-1933 YEARS
}

\section{Abstract}

The article aim is to clarify significance of «The black deeds of the Kremlin: A white book» in respect to preservation Ukrainian nation historical memory and informing the world community about Holodomor (1932-1933 years) in Ukraine. The research methodological basis is fundamental principles of scientific cognition such as historicism, scientific nature, credibility and consistency. A number of specific historical methods are employed in the research to attain the outlined goal. They include a method of bibliography heuristics that helped to search for historiographic sources depending on the research topic. The methods of source analysis and synthesis encouraged a book critique interpretation. The bibliography method provided an acquaintance with the life course of Semen Pidhainii. He was the editor-in-chief of «The black deeds of the Kremlin: A white book». The research novelty is that it clarifies importance of "The black deeds of the Kremlin: A white book» in preservation of Ukrainian nation historical memory and informing the world community about Holodomor (1932-1933 years) in Ukraine. Consequently the author concludes that the two-volume edition is of tremendous significance for preservation of Ukrainian nation historical memory since it is the first profound collection of Holodomor (1932-1933 years) victims' testimonies in Ukraine. At the same time «The black deeds of the 
INTERMARUM: history, policy, culture. - Issue 7.

Kremlin: A white book» played an important role in informing the world community about Holodomor (1932-1933 years) in Ukraine.

It was published in the English and soon Spanish languages encouraging informing the world community about the criminal activity of Stalin regime against the Ukrainian nation. The two-volume book was used at the International Commission meeting dedicated to the investigation of Holodomor (1932-1933 years) in Ukraine. The United States Congress initiated the meeting. The Commission came to a decision that events in Ukraine (1932-1933 years) are reasonable to qualify as a genocide of the Ukrainian nation.

Key words: Holodomor 1932-1933 years in Ukraine, "The black deeds of the Kremlin: A white book», Semen Pidhainii.

Introduction. "Any violent death is horrible when people are shot, hung, smothered... It lasts seconds, minutes. And a murder as a result of hunger lasts for weeks, months. A death from hunger is the death without blood. Blood doesn't stream, blood gradually gets cold. Everybody died from hunger both men and women, both old and young people. Whole families and villages died out" (Kovalenko, Maniak, 1991, p. 367).

The lines are taken from Pavlo Avramenko testimonies published in the book «33s: Hunger: National Book-Memorial». It came out in last months of the USSR existence. Almost 60 years passed since the tragedy to the first testimonies collected by scholars in Soviet Ukraine. Certainly there was no similar work in the USSR during Stalin and Brezhnev regimes. But it was carried out by some Ukrainian emigrants who managed to leave the Soviet Union and settle in different European and American countries. They regarded testimonies about crimes of Stalin regime as their social obligation for future scientists and successive generations.

There are no special researches in historical science that would analyze significance of the two-volume collection «The black deeds of the Kremlin: A white book» in respect to preservation Ukrainian nation historical memory and informing the world community about Holodomor (1932-1933 years) in Ukraine. The book was mainly used as a research source of the Ukrainian nation genocide. Particular scholars addressed to the mentioned work in different times. In his 
IНТЕРМАРУМ: історія, політика, культура. - Вип. 7.

article, Bohdan Klid (Klid, 2014, pp. 463-475) presented a general analysis of the two-volume collection focusing on history of its creation. Hennadii Boriak (Boriak, 2009, pp. 37-38) revealed the book transition into Spanish. It enabled to learn the work for the Spanish-speaking world.

The research aim is to clarify significance of «The black deeds of the Kremlin: A white book» in regards to preservation Ukrainian nation historical memory and informing the world community about Holodomor (1932-1933 years) in Ukraine.

Results and Discussion. The highest number of Ukrainian immigrants moved west during World War II and the first years of its ending. The important thing is that intellectuals constituted a high percentage of migrants. Prominent scientific, pedagogical and art individuals were among them. In addition migrants included some representatives of the resistance movement in particular OUN and UIA combatants who fought with Soviet military units. The clergy and members of their families, peasants were also involved in the trend. Migrants represented different regions of Ukraine and had their own political biography. Former prisoners of Stalin concentration camps, Ukrainian patriots and high-principled people, victims of Holodomor and resolute fighters against Bolshevik tyranny were among them. In such a way the third wave of emigration from Ukraine had a political character.

Settling in postwar years from Germany and Austria, displaced people and refugees from Ukraine aspired to appear predominantly in the USA and Canada. Attractiveness of mentioned countries for them was explained by presence of Ukrainians in America and Canada for about half a century there. They were representatives of two emigration waves. The second reason was a US position and its allies towards the USSR during «the Cold War». Overcoming difficulties with a legalization of numerous documents, going through all commissions and travels on the ship from Europe to North America Ukrainians could finally feel themselves free after many years of hardship. They got a long expected affidavit.

The third emigration wave representatives induced a new trend into a Ukrainian life within the USA and Canada. Despite some difficulties related to an adaptation, searches for accommodation and job, former 
INTERMARUM: history, policy, culture. - Issue 7.

displaced people and refugees actively proceeded to setting up a Ukrainian cultural, public and political life. In such a way they tried not only to preserve their national «I» but put off an assimilation and acculturation, preserve a historical memory of the Ukrainian nation and inform the world community about Stalin repressions. Aspiration of Ukrainians to create their own state were also important.

The beginning of this activity dates back to a life of Ukrainians in postwar Germany and Austria. It's the establishment of various educational institutions, undertaking studies, founding theatres, restoration or creation of political parties, arrangement of publishing activity, delivering speeches and lectures in camps, organization of celebrations and remembrance days. No wonder the Ukrainian emigrants founded a number of public organizations in the USA and Canada at the beginning of 1950s. There were members of Ukrainian Revolutionary Democratic Party among initiators of such institutions. The political party was founded by Kyryl Datsko in postwar Western Germany. The writer Ivan Bahrianii was a party leader and ideologist. He couldn't emigrate to Germany for health reasons. That's why the party management center remained in Europe for subsequent years. However most his party members and adherents moved to countries of western democracy establishing a range of URDP committees and offices. The USA and Canada were no exceptions.

In New-York on the 22 of January at the initiative of mainly URDP members, Kyryl Datsko, Ivan Dubynets, Fedir Rachko, Pavlo Shynkar and others established the Democratic Union of former repressed Ukrainians suffered from the Soviet regime. They lived in the United States of America (DUFRU in the USA). In the end of the same year the Union of Ukrainians (victims of Russian and communist terror) was brought into the world in Canada. It took place under the auspices of historian, public figure and member of URDP Semen Pidhainii. In NewYork (1954 year) the World Federation of Ukrainians was established at the common meeting of DUFRU and VRCT representatives. They were former political prisoners and repressed people. Semen Pidhainii was elected as the president of the Bureau (Central State Archive-Museum of Literature and Art of Ukraine. F. 1186. Op. 2. D. 115. L. 4).

In subsequent years DUFRU and VRCT made great efforts to inform the world community about crimes of Stalin regime towards the 
IНТЕРМАРУМ: історія, політика, культура. - Вип. 7.

Ukrainian nation. Emigrants realized that their activity must push leading western politicians to blame publicly crimes of Stalin regime in respect to the Soviet nations giving them help to determine their own national direction. Ukrainian Congress Committee of America was involved in this work led by the head Lev Dobrianskyi. A similar organization is located in Canada. It's called the Ukrainian Canadian Congress. A great deal of Ukrainian public organizations acceded to these institutions including DUFRU and VRCT. According to the statutes of DUFRU and VRCT the organization tasks encompass a collecting of documentary materials about crimes of Stalin policy towards Ukraine and informing the USA and Canada governments about this. Moreover they include giving help to the Ukrainian nation to fight for its independent and united nation. Some other tasks deal with an arrangement of demonstrations and cooperation with similar national organizations Konoval, 1997, pp. 414-415, 428).

A pamphlet «Why I don't want to come back to the USSR? » written by Ivan Bahrianii is considered to be the vital document and ideological basis of DUFRU and VRCT activity. Ivan Bahrianii was a VRCT honorary member. The fields of these organizations activity were highlighted within some constituents of «new serfdom» and Bolshevism (a forced collectivization, artificially organized Holodomor 1932-1933 years in Ukraine, repressions against Ukrainian intellectuals, violation of human rights and antireligious campaigns). During the years of DUFRU and VRCT activity in the USA and Canada a lot of things were done to achieve the aim mentioned in the organization statutes.

In the first half of 1950s the DUFRU and VRCT members under the leadership of Semen Pidhainii contributed money to publish the twovolume collection under the eloquent title «The black deeds of the Kremlin: A white book» (the second volume together with VRCT) (Pidhainy, Vol. 1, 1953; Pidhainy, Vol. 2, 1955). Semen Pidhainii (1907-1965) was the one who initiated the two-volume book publication dramatically.

Semen Pidhainii is a historian, columnist, public and political figure. He studied at the faculty of professional education (Kyiv institute of public education). He completed postgraduate studies at Kharkiv scientific and research institute of material culture. At the beginning of 1930s he worked at Kharkiv institute of public education and within the 
INTERMARUM: history, policy, culture. - Issue 7.

structure of Ukrainian Academy of Sciences. During 1933-1941 years he was imprisoned on the Solovetsky Islands. He moved to Germany together with his family in the years of World War II. Soon he went to Canada and started building a Ukrainian public and political life. Being in Western Germany he published two works «Undershot» (about representatives of $1920 \mathrm{~s}$ generation who were lucky to survive) and «Ukrainian intellectuals on Solovky» revealing a criminal activity of USSR top ranking officials in light of dissidence oppression.

Visiting Canada Semen Pidhainii encouraged during meetings former displaced people and refugees to write memoirs about repressions they underwent in USSR (Klid, 2014, p. 479). Soon the editorial board was established under his leadership. In early 1950s it compiled, translated into English and published the two-volume collection «The black deeds of the Kremlin: A white book». Due to lack of sources, hard to say whether the editorial board edited / proofread the received texts or they were published in the original author's edition. Besides there is still a question whether the source evidences have been preserved until nowadays and if they have, in which archive they are kept.

In the two-volume book «The black deeds of the Kremlin: A white book» you get to know materials that reveal crimes of Stalin regime against the Ukrainian nation in particular repressions against intellectuals, clergy and peasants. Testimonies of Holodomor witnesses are of special importance especially those who managed to leave the Soviet Union and settle in the USA and Canada. They are added by published documents that reveal, for example, a course of dispossession process in Ukraine, fulfillment of bread stocking plans (Pidhainii, Vol. 2, 1955, pp. 301, 383, 385, 417, 425). Photo materials are also published where victims of 1930 year hunger are pictured (Pidhainy, Vol. 2, 1955, pp. 444, 457, 494, 515, 538, 554, 560, 595, 653, 692, 701). Special emotions trigger off pictures of children who don't hope for help anymore. However, compilers of the two-volume book didn't indicate the original source of these pictures.

A coverage of Holodomor (1932-1933) testimonies in Ukraine placed within «The photographs.of the Kremlin: A white book» is dramatic. The highest number of respondents come fphotographs. Kyiv, Kharkiv and Dnipropetrovsk regions. Sporadic testimonies were 
IНТЕРМАРУМ: історія, політика, культура. - Вип. 7.

obtained from repphotographs. of Vinnytsia, Zhytomyr, Mykolaiv, Summy, Cherkasy and Chernihiv regions including Donbphotographs.timonies are written by peasants, collective farm members or employees. The representation of intellectuals constitutes a small percentage among authors. The writers Oleksa Hai-Holovko and Yar Slavutych are engaged in the first volume. A historian Fedir Pravoberezhnii, a writer Polikarp Kybkalo are mentioned in the second volume (Pidhainii, Vol. 1, 1953, pp. 291-296, 299-301; Pidhainy, Vol. 2, 1955, pp. 635, 566).

It should be noted that one-third of the respondents didn't indicate their names and surnames. They just mentioned cryptonyms mainly two-letter ones (probably letters coincide with name and surname initials). For example, the Vol. 1 comprises P. V., I. Kh., Y. P.; the Vol. 2 includes L. M., B. A., M. T., S. K. (Pidhainii, Vol. 1, 1953, pp. 213, 260-261, 262; Pidhainii, Vol. 2, 1955, pp. 541, 558, 559, 580). In turn some respondents took down their pseudonyms. For instance, the author of chapter «Hunger as a political method» T. Sosnovii signed as Petro Dolyna. A historian Fedir Pihido presented his testimonies under the pseudonym F. Pravoberezhnii (Pidhainy, Vol. 2, 1955, pp. 5, 635). The usage of cryptonyms and pseudonyms comprised a rational survival strategy of the Ukrainian emigrants who had a good reason to be afraid of the Soviet intelligence.

Living in the USA and Canada Ukrainian political emigrants credibly told their life stories about the Stalin regime. They wrote testimonies for the world to know about their past and a similar destiny of their compatriots who stayed in the USSR (Pidhainii, Vol. 1, 1953, p. VII). In general their reminiscences are proved by archive materials, photo sources from 1930s years, Holodomor victims' testimony collected on the territory of Ukraine in the late $20^{\text {th }}$ and early $21^{\text {st }}$ centuries

Children suffered terrifically in 1930 year when hunger times were in full swing. In Holodomor period the education process continued at schools. According to the testimony of Vasyl Mirytenko from Zhytomyr region pupils were given «hot breakfasts» in winter (1932/1933 years). The witness told about recipe peculiarities of such breakfasts. A little flour is mixed with water, salted and boiled. The dish was called «zatirka» and every pupil was provided with 200-300 grams. When 
INTERMARUM: history, policy, culture. - Issue 7.

spring came a little bit sorrel and a few potatoes were added to «zatirka». Finally a new dish «borshch» appeared (Pidhainii, Vol. 2, 1955, p. 574).

Foodstuff prices went through the roof under the shortage of products.Tetiana Byrko from Poltava region said that a bottle of milk cost 70 roubles in hunger times. In its turn, a little loaf of bread could be bought for 100 roubles (Pidhainy, Vol. 2, 1955, p. 575).

Holodomor (1932-1933 years) in Ukraine had an influence on the people psychological state of mind. They suffered from hunger. A new horrible phenomenon became popular. It was cannibalism. A separate chapter is dedicated to this issue in the second volume of «The black deeds of the Kremlin: A white book». The terrific reminiscences sound as follows, «He cooked his dead mother's hand», «We ate father», «She killed her nine-year-old daughter», «Cannibalism in the region of Vynnytsya» (Pidhainy, Vol. 2, 1955, pp. 650, 653, 658).

In its turn, Yar Slavutych informed about a tragedy that took place in the village Obitoky of Dolyna area (Dnipropetrovsk region). In the end of 1932 year a former flourishing and hospitable woman under the name of Vekla lost her mind from hunger and killed her own daughter. She could be full for some time because of that. Soon realizing what she did, Vekla confessed. She was arrested and taken to Solovky (Pidhainii, Vol. 1, 1953, pp. 300-301).

Let us figure out whom the respondents blamed for the artificially arranged hunger in Ukraine during 1930s years. In most statements accusations are missing. The authors of reminiscences told about some events from their own life, friends' and neighbors' lives. Only some respondents pointed at initiators of Holodomor. As a rule they did it impersonally. Mykola Stefan from Poltava who was 10 years old in the beginning of 1930s told about armed gangs under the name «cheka». These gangs went to villages of Ukraine looking for foodstuffs and seizing them (Pidhainy, Vol. 1, 1953, p. 285).

The efforts taken by DUFRU and VRCT to collect, combine and translate information into English, public testimony about Holodomor (1932-1933) in Ukraine are of great importance. It was the first fundamental collection of reminiscences on the problem. It played an important role in historical memory preservation of the Ukrainian nation and formation of Ukrainian national identity in emigration. Memories 
IНТЕРМАРУМ: історія, політика, культура. - Вип. 7.

about tragic moments, historical experience of Ukrainians in 1932-1933 years are fixed in the two-volume collection. They were passed to consciousness of Ukrainian emigrants, diaspora members and next generations. Holodomor memory became a bridge between past and future determining some memory policy priorities. Ukrainian intellectuals in the USA and Canada constructed knowledge about Holodomor (1932-1933 years) in Ukraine through the interpretation of history, textbook publishing for Ukrainian schools, delivering lessons of memory, creation of art items, arrangement of commemoration days, putting up monuments and installation of memorial symbols, mass media publications etc.

Ukrainian public organizations in the USA and Canada made efforts to inform the general public and mainly world political community about the two-volume collection.

More than two thousand books from 15 thousand copies of «The black deeds of the Kremlin: A white book» were sent to all United Nations delegation heads including the Soviet Union representative Andrii Vyshynskyi, presidents and prime ministers, policymakers and ministers of different countries worldwide.

Hundreds of copies were sent to scientific and political institutions, higher educational establishments, libraries, editorial boards of leading European journals (Pidhainii, 2008, p. 8; Central State Archive-Museum of Literature and Art of Ukraine. F. 1186. Op. 2. D. 115. L. 3). All those who wish could buy the two-volume collection. The first volume cost 5 (soon 3) dollars and the second one cost 7 dollars (Central State Archive-Museum of Literature and Art of Ukraine. F. 1186. Op. 2. D. 115. L. 6, 49). Books were sold in book stores and meetings dedicated to Holodomor commemoration dates (Central State ArchiveMuseum of Literature and Art of Ukraine. F. 1186. Op. 2. D. 115. L. 31-32, 36). In addition books were spread by enthusiastic individuals who aspired to reveal the truth about a Soviet »paradise» for those who often jumble up the things (Central State Archive-Museum of Literature and Art of Ukraine. F. 1186. Op. 2. D. 115. L. 7).

Both volumes were translated into the Spanish language in the second half of 1960 year. It's one of six UN official languages (The black deeds of the Kremlin: A white book. Vol. 1, 1966; The black deeds of the Kremlin: A white book. Vol. 2, 1967). 
INTERMARUM: history, policy, culture. - Issue 7.

But before publishing the two-volume collection and its inclusion into the scientific field (that time scientific community didn't notice the two-volume book except for a fragmentary mentioning in works by Dan Darlimpl; there were no foreign-language reviews of the two-volume book of that time detected) and active usage when investigating Holodomor circumstances.

In the second half of 1980 years the US Congress established the International commission on hunger investigation in Ukraine during 1932-1933 years. «The black deeds of the Kremlin: A white book» was employed when investigating the case. The Commission aim was to explore Ukrainian hunger in 1932-1933 years in order to expand knowledge of world community about hunger. One more thing was significant. It was to provide the American society with better understanding of the Soviet system via a role of USSR high ranking officials in Hunger.

The report of the International commission on hunger investigation in Ukraine during 1932-1933 years pointed out that the second volume of «The black deeds of the Kremlin: A white book» with the subheading «The Great Famine in Ukraine in 1932-1933» encompasses the bulk of documents and witness testimonies concerning Hunger» (Great Famine in Ukraine 1932-1933. Vol. IV, 2008, p. 39). Analyzing witness testimonies both published and collected by the Commission independently as well as history papers on the problem the Commission made the following conclusions:

"1. There is no doubt the majority of Soviet Ukraine and North Caucasian Region inhabitants died from starvation during artificially organized hunger (1932-1933 years) caused by actions of Soviet authority. It expropriated crop in 1932 year.

2. Hunger took millions of lives in Ukraine.

3. Ukrainian Hunger in 1932-1933 years brought about the expropriation of peasant agricultural products.

4. Officials who expropriated grain also lived in fear of punishment.

5. In the end of 1932 year Stalin knew that people died from hunger in Ukraine.

6. P. Postyshev got the double task from Moscow. It was to intensify the expropriation of grain in Ukraine and destroy specific 
IНТЕРМАРУМ: історія, політика, культура. - Вип. 7.

manifestations of national self-determination the USSR administration had permitted before.

7. During the agricultural year in 1932-1932 years hunger also encompassed the Volga Basin and North Caucasian Region in general. The Kuban was inhabited by ethnic Ukrainians where aggressiveness of Stalin policy was the same in Ukraine as in Autumn of 1932 year and January of 1933 year.

8. In 1932-1933 years Yosyp Stalin and his closest surrounding committed a genocide against Ukrainians" (Great Famine in Ukraine 1932-1933. Vol. IV, 2008, pp. 7-8).

Conclusions. The two-volume collection «The black deeds of the Kremlin: A white book» is the first fundamental book of Holodomor (1932-1933 years in Ukraine) victims testimony. It contains reminiscences of Ukrainians who emigrated from the USSR to the USA and Canada in a post-war period. The book embodied the major contribution of the third wave Ukrainian emigrants preserving historical memory of the Ukrainian nation. The two-volume collection is a valuable historical source on the issue. It should be mentioned that nearly 20 years passed since tragic times of 1930 year. Researchers started collecting testimonies of hunger just in the end of 1980 years. That's why the authors of reminiscences were close to that tragic events and could highlight Holodomor information thoroughly and vividly. «The black deeds of the Kremlin: A white book» was published in English and Spanish. It encourage informing the world community about a criminal activity of Stalin regime against the Ukrainian nation. The collection was used during the investigation of hunger (1932-1933 years in Ukraine) by the International Commission arranged under the auspices of the United States Congress. The Commission came to a conclusion that events taking place in Ukraine that time are reasonable to qualify as the genocide against the Ukrainian nation.

\section{BIBLIOGRAPHY}

Boriak, H. (2009). Sources for the Study of the Great Famine in Ukraine. Cambridge: Ukrainian Studies Fund. 60 p. [In Ukrainian].

Central State Archive-Museum of Literature and Art of Ukraine. F. 1186. Op. 2. D. 115. 1451. 
INTERMARUM: history, policy, culture. - Issue 7.

Great Famine in Ukraine 1932-1933. (2008). (in IV vols, Vol. IV). Kyiv: Kyievo-Mohylianska akademiia. 622 p. [In Ukrainian].

Klid, B. (2014). «The Black Deeds Of The Kremlin: A White Book»: Sixty Years Later. (M. Soroka, Ed.) Zakhidnokanadskyi zbirnyk, (XLVII. Part seven), 463-475. [In Ukrainian].

Konoval, O. (Comp.) (1997). Ukrainian Revolutionary Democratic Party (URDP-UDRP): Collection of Materials and Documents. Chicago; Kyiv: Fundatsiia im. Ivana Bahrianoho. 856 p. [In Ukrainian].

Kovalenko, L., Maniak, V. (1991). 33rd: Hunger: The People's Book Memorial. Kyiv: Radianskyi pysmennyk. 584 p. [In Ukrainian].

Pidhainii, S. (2008). Ukrainian intelligentsia in Solovki. Not shot. Kyiv: Vyd. dim «Kyievo-Mohylianska akademiia». 326 p. [In Ukrainian].

Pidhainii, S. (Editor-in-chief) (1953). The black deeds of the Kremlin: A white book. (2 Vols, Vol. 1). Toronto: Ukrainian association of victims of Russian communist terror. XIV p. + 545 p. [In English].

Pidhainii, S. (Editor-in-chief) (1955). The black deeds of the Kremlin: A white book. (2 Vols, Vol. 2). Detroite: DOBRUS. XXIV p. + 712 p. [In English].

The black deeds of the Kremlin: A white book (1966). (2 Vols, Vol. 1). Buenos Aires. 633. [In Spanish].

The black deeds of the Kremlin: A white book (1967). (2 Vols, Vol. 2). Buenos Aires. 797. [In Spanish].

\section{Подобсд Олена. «THE ВLACK DEEDS OF THE KREMLIN: A WНITЕ ВООК». УКРӒ̈НСЬКІ ЕМІГРАНТИ СВІДЧАТЬ ПРО ГОЛОДОМОР 1932-1933 РОКІВ}

\section{Анотація}

Метою статті є з'ясування значення «The black deeds of the Kremlin: A white book» y збереженні історичної пам'яті украӥнського народу та в інформуванні світової громадськості про Голодомор 1932-1933рр. в Украӥні. Методологічну основу дослідження становлять базові принципи наукового пізнання: історизму, науковості, об'єктивності, системності. Для реалізації поставленої у дослідженні мети використано низку спеціальноісторичних методів: метод бібліографічної евристики було застосовано під час пошуку історіографічних джерел з теми 
IНТЕРМАРУМ: історія, політика, культура. - Вип. 7.

дослідження; за допомогою методів джерелознавчого аналізу $i$ синтезу здійснювалася джерелознавча критика; використання біографічного методу допомогло вивчити особливості життєвого шляху головного редактора двотомника "The black deeds of the Kremlin: A white book» Семена Підгайного.

Наукова новизна розвідки полягає в тому, що у ній уперше з'ясовано значення "The black deeds of the Kremlin: A white book»y збереженні історичної пам'яті украӥнського народу та в інформуванні світової громадськості про Голодомор 1932-1933 рр. в Україні. У результаті авторка приходить до висновку, щзо двотомник має непересічне значення у збереженні історичної пам'яті українського народу. Адже - ие перший фундаментальний збірник свідчень жертв Голодомору 1932-1933 рр. в Україні. Водночас збірник «The black deeds of the Kremlin: A white book» відіграв вагому роль в інформуванні світової громадськості про Голодомор 1932-1933 рр. в Україні. Виданий англійською та згодом іспанською мовами, він сприяв інформованості світової громадськості про злочинну діяльність сталінського режиму проти українського народу. Двотомник було використано у ходi роботи Міжнародної комісї з розслідування голоду 19321933 років в Україні, організованої Конгресом США. Комісія дійшла висновку, щьо подї 1932-1933 рр. в Украӥні правомірно кваліфікувати як геноцид українського народу.

Ключові слова: Голодомор 1932-1933 рр. в Україні, The black deeds of the Kremlin: A white book», Семен Підгайний.

\section{Podobied Olena. “CZARNE CZYNY KREMLA: BIALA KSIEGA”. EMIGRANCI UKRAIŃSCY ŚWIADCZĄO HOLODOMORZE w LATACH 1932-1933}

\section{Streszczenie}

Celem tego artykutu jest wyjaśnienie znaczenia "Czarne czyny Kremla: Biała Ksiega”" w zachowaniu pamięci historycznej narodu ukraińskiego oraz $w$ informowaniu świata o Hołodomorze $w$ latach 1932-1933 na Ukrainie. Baza metodologiczna badań sa podstawowe zasady poznania naukowego: historyzm, naukowość, obiektywizm, systematyczność. Do realizacji celu danego badania wykorzystano szereg metod właśnie historycznych: do poszukiwania źródet 
INTERMARUM: history, policy, culture. - Issue 7.

historiograficznych $w$ temacie badawczym zastosowano metode heurystyki bibliograficznej. Za pomoca metod źródtowej analizy $i$ syntezy przeprowadzono krytykę źródtowa. Zastosowanie metody biograficznej pomogło zbadać osobliwości ścieżki życiowej redaktora glównego dwutomnej ksią̇ki "Czarne czyny Kremla: Biała Księga" Semena Pidgajnego. Oryginalnościq naukowa badania jest to, że po raz pierwszy autorka wyjaśnita znaczenie "Czarne czyny Kremla: Biała Księga” w zachowaniu pamięci historycznej narodu ukraińskiego oraz $w$ informowaniu społeczeństwa o Holodomorze na Ukrainie $w$ latach 1932-1933. W rezultacie autoka podsumowuje, że ta ksiązka ma ogromne znaczenie dla zachowania pamięci historycznej narodu ukraińskiego. Ponieważ, ona to pierwszy fundamentalny zbiór świadczeń ofiar Holodomoru na Ukrainie $w$ latach 1932-1933. Jednocześnie kompilacja "Czarne czyny Kremla: Biała Ksiażka" odegrata znaczaca role $w$ informowaniu międzynarodowej spoteczności o Holodomorze na Ukrainie $w$ latach 1932-1933. Zbiór zostat opublikowany $w$ języku angielskim, a następnie hiszpańskim, co promowato wśród spoteczności międzynarodowej świadomość o przestępczości reżimu Stalina wobec narodu ukraińskiego. Dwutomowa ksiązka została wykorzystana podczas pracy Międzynarodowej Komisji do zbadania głodu na Ukrainie w latach 1932-1933, zorganizowanej przez Kongres USA. Komisja doszła do wniosku, że wydarzenia 1932 1933 na Ukrainie zostały zgodnie z prawem uznane za ludobójstwo narodu ukraińskiego.

Stowa kluczowe: Holodomor na Ukrainie w latach 1932-1933, "Czarne czyny Kremla: Biała Ksiega", Semen Pidgajny.

The article was received 09.01.2019 Article recommended for publishing 10.31.2019 